\title{
湘南海岸における砂防柵設置による微地形と風環境の変化が飛砂害に 及ぼす影響
}

\section{吉㟝真司 $\left.{ }^{* 1}\right) \cdot$ 長島大輔 2) - 清水带里沙 3 )}

1）東京都市大学環境学部 Faculty of Environmental Studies, Tokyo City University

2）株式会社オリエンタルコンサルタンツ Oriental Consultants Co.,Ltd

3）武蔵工業大学環境情報学部（現：主婦）Musashi Institute of Technology (at present:Housewife)

摘要 : 飛砂害が激しい神奈川県湘南海岸において, 砂防柵設置による微地形と風環境の変化が飛砂害に及ぼす影響を把握するため に, 2008 年と 2014 年に微地形, 風環境（風向・風速）, 飛砂量等の調査を行った。その結果, 飛砂害の発生要因として, 砂移動 の障害となる砂防柵や植生の有無, 防風柵の設置位置による減風域の範囲や微地形の変化が考えられ，これらが相互に関連し合う 結果, 自転車道への堆砂量（飛砂害）にも影響を与えることがわかった。本研究の結果は，自転車道への飛砂害を制御し，背後の 海岸防災林内への飛砂の侵入を抑制するとともに飛砂や潮風から樹木を健全に維持するなど，海岸防災林の維持・管理にとっても 重要な示唆を与えるものと考えられた。

キーワード : 微地形, 風環境, 飛砂害, 砂防柵, 海岸防災林

YOSHIZAKI, Shinji, NAGASHIMA, Daisuke and SHIMIZU, Arisa: Effects of the change of topographic and wind conditions by constructing sand fence on shifting sand damage at sandy beach in Shonan coast, Kanagawa Pref., Japan

Abstract: Micro topographic change, wind conditions(wind velocity,wind direction) and the accumulation of shifting sands etc. were surveyed to verify the effect of the change of topographic and wind conditions by constructing sand fence on shifting sand damage in 2008 and 2014 at Shonan beach, Kanagawa Pref., Japan. As a result, It was considered that the factors of shifting sand damage were (a)existance of artifitial wind or sand barrier, (b)change of wind reduction range by the position of wind barrier. It was also cleared that the manner of accumulated amount of sand was different in each conditions (a)and(b). Those results showed important suggestions for maintenance and management of coastal forest behind beach.

Key words: micro topography, wind condition, shifting sand damage, sand fence, coastal forest for disaster prevention

\section{1. はじめに}

我が国の沿岸域に住む人々は, 海からの強風によって常に 飛砂害に悩まされてきた 6 。 最近では海岸防災林の造成や建 物の性能向上等によって飛砂害は減少しているものの，防災 林の前面への自転車道や遊歩道建設等に伴う飛砂害は依然と

して多い2)。

飛砂の発生と供給源である砂浜は, 強風・潮風・飛砂・強 い日射・貧栄養・乾燥といった植物の生育にとって非常に㛜 しい環境下にある 3)。そのために，これらの環境変化によっ て起こる攪乱に耐性または適応力がある海浜植物が汀線から 内陸へ向かって, 不安定帯, 半安定帯, 安定帯という大きな 環境の傾度に沿って種構成や植被の状況を変化させながら群 落を形成していくと考えられる 8)。一方、我が国の沿岸域の 多くは人の手によって植栽・育成されたマツ類を主とする海 岸防災林が広く成立しているが，多くは松枯れによって劣化 しており，本来発揮すべき防風や防砂、潮害防備といった機 能の発揮が困難になっている 17)。海岸林がこれらの機能を発
揮するためには樹高の高い健全な樹林が必要であり，それを 維持するためには安定した砂浜と飛砂の発生を抑制する海浜 植生の存在が有効である。更に, 2011 年に発生した東日本大 震災において, 東北地方太平洋岸の海岸防災林が壊滅的なダ メージを受けたことは記憶に新しい9）今後発生が予想され る南海トラフ地震と津波の被害が心配される関東以西の太平 洋岸においては災害に強い海岸防災林の造成が進められてい る 1)が，海岸防災林の造成や維持にあたっては樹林前面の微 地形の検討や飛砂の発生状況の把握が必須である。

そこで, 砂面変動が激しい神奈川県藤沢市の湘南海岸にお いて, 2008 年と 2014 年に微地形や風環境等の調查を行い, 微地形と風環境の変化が自転車道への飛砂害に及ぼす影響を 明らかにすることを目的に研究を行った。

\section{2. 材料ならびに方法}

調査地は神奈川県湘南海岸の自転車道とその前面の砂浜で ある（図-1）。自転車道は，総延長 $8.4 \mathrm{~km}$, 幅員 $3 \sim 4 \mathrm{~m}$ の アスファルト舗装である（写真-1）が，図-1に示すように，

\footnotetext{
*連絡先著者（Corresponding author）：=224-8551 横浜市都筑区牛久保西 3-3-1 E-mail : shin@tcu.ac.jp
} 


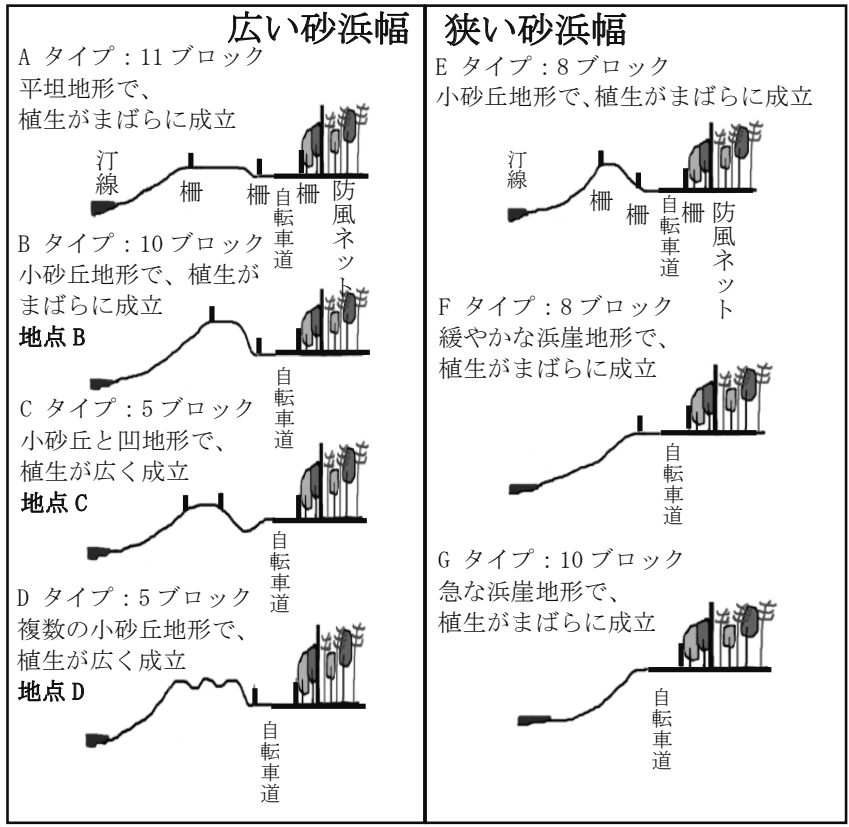

図-3 砂浜幅と微地形による後浜の形状 (タイプ)

Fig. 3 Profile of beach type with the width of beach and its micro topography

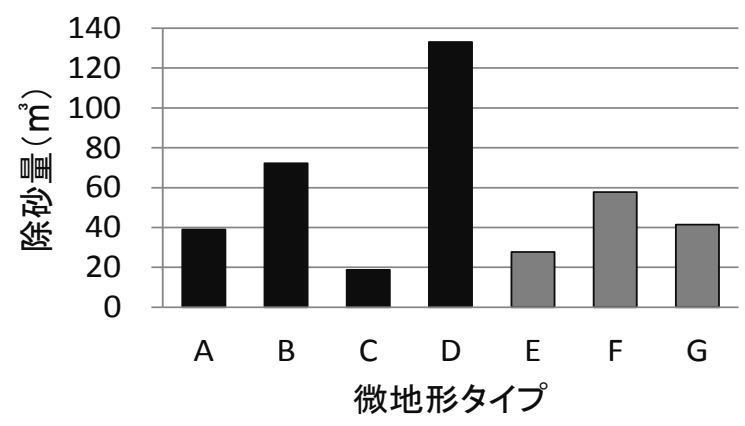

図-4 後浜の形状タイプごとの除砂量 $\left(\mathrm{m}^{3}\right)$

Fig. 4 Removal sands in each beach type $\left(\mathrm{m}^{3}\right)$

間の連続測定を行った後に移動するという方法で実施した。 また，砂防柵の前後も測定した。なお移動点の風速は，基準 点の風速を 100 とした相対風速比(\%)として算出し解析を行 った。2014 年調査は， 9 月 24 日，10月 2 ・ 3 日に，2008 年 と同じ場所で，かつ同じ方法で調查を行ったが， 2014 年調査 では，基準点風速測定にはノースワン社（KDC-S4）の風向 - 風速計を, 鉛直方向の計測には太田計器製作所 26-D 風速 計を用いた。

\section{4 除砂量及び堆砂量調査}

神奈川県藤沢土木事務所から提供を受けた除砂量データの うち，整理されていた $2002 ・ 2004 〜 2006$ 年のデータを用い て対象とした地点 $\mathrm{B}, \mathrm{C}, \mathrm{D}$ の年間除砂量を集計した。除砂 量は $4 \mathrm{~m}$ (自転車道幅 $) \times 100 \mathrm{~m}$ (ブロック距離 $)=400 \mathrm{~m}^{2}$ の 自転車道上の砂を排除した量としてブロックごとに表した。

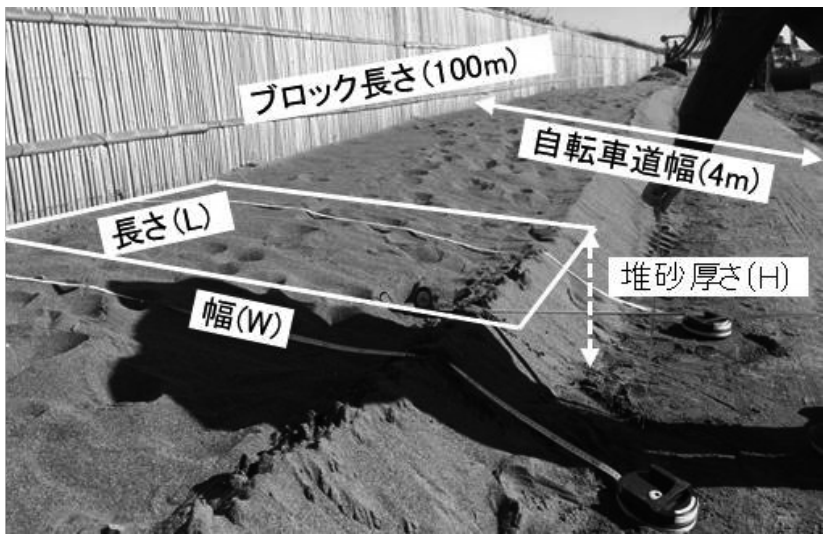

図-5 除砂直前の砂の状況と測定項目 (2014 年 12 月 19 日)

Fig.5 Measurement of accumulated sands before removing

また 2014 年の堆砂量は, 2014 年 12 月 19 日に, 各調査地点 の自転車道上に堆積している砂の容量を調査した。自転車道 に $50 \mathrm{~cm}$ 間隔で 3 本の測線を引き, $10 \mathrm{~cm}$ ごとに堆積した砂 の高さを定規とコンベックスを用いて計測し, 堆積した砂の 平均厚さから単位面積当たりの堆砂量を算出した(図-5)。な お, 飛砂は自転車道上に均一に堆積していないが連続してい ることから， $4 \mathrm{~m}$ (自転車道幅 $) \times 100 \mathrm{~m}$ (ブロック距離 $)=400$ $\mathrm{m}^{2}$ に一様に堆積したものとして計算した。

\section{3. 結果と考察}

\section{1 微地形及び植生の変化}

表-1 に 2008 年と 2014 年の砂防柵（以下，「柵」）の有無, 砂浜幅, 植生の有無, 植生幅の変化を, 図-6 に各調査地点に おける断面地形の変化, 植生の変化, 柵の位置を示す。なお, 図中の X 軸が示す「砂浜の幅」は, 自転車道の南縁から汀線 方向への水平距離 $(\mathrm{m})$ を示す。

地点D : 2008 年に存在した柵 $\mathrm{a}$ は崩壊し, 新たに主風向に 対して斜めに柵 b が設置されていたが，これもまたほぼ砂中 に埋没していた。丘頂は、6 年の間に $15 \mathrm{~m}$ 汀線側へ移動し, 柵 $\mathrm{b}$ と自転車道との間に大きな凹地形が形成されていた。植 生 1 は、2008 年には砂丘南面に一列に成立していたが、2014 年では柵 b の風背側で衰退し, 自転車道と凹地の間に新たに 植生 3 が成立していた。

地点 B : 2008 年に存在していた 2 列柵 $\mathrm{a} ・ \mathrm{~b}$ は砂中に埋没 し，新たに 1 列柵 $\mathrm{c}$ が確認された。最大比高の位置が自転車 道から $10 \mathrm{~m}$ の位置に移動し, 比高も低下した。すなわち, 砂丘自体が低く小さくなり, 砂浜の地表面は自転車道より低 い位置に存在することになった。

地点 C : 2008 年には自転車道から $15 \mathrm{~m} \sim 25 \mathrm{~m}$ 付近で砂丘 が形成されていたが、2014 年は柵 $\mathrm{c} ・ \mathrm{~d}$ の影響により, 自転 車道から $7 \mathrm{~m}, 25 \mathrm{~m}$ 付近の 2 か所に砂丘が形成されていた。 更に, 2008 年では植生 1 は一列に $20 \mathrm{~m}$ 成立していたが, 2014 年では植生は 2 と 3 の 2 所に分かれて成立していた。 
表-1 調査地点ごとの砂浜幅, 植生, 柵の変化

Table 1 Change of the width of beach, vegetation and sand fence from 2008 to 2014

\begin{tabular}{lcccccc}
\hline \multicolumn{1}{c}{ 地点 } & \multicolumn{2}{c}{$\mathrm{D}$} & \multicolumn{2}{c}{ B } & \multicolumn{2}{c}{$\mathrm{C}$} \\
\hline 西暦年 & 2008 & 2014 & 2008 & 2014 & 2008 & 2014 \\
& 1 列 & 1 列 & 2 列 & 1 列 & 3 列 & 1 列 \\
砂防柵 & 有り & 埋没 & 有り & 斜め & 有り & 有り \\
& 80 & 82 & 67 & 82 & 69 & 78 \\
砂浜幅 $(\mathrm{m})$ & 有り & 有り & 無し & 無し & 有り & 有り \\
植生 & 26.5 & 12.1 & 0 & 0 & 41.8 & 9.5 \\
植被率(\%) & 31 & 30 & & & 20 & 12 \\
& $(1$ 列 $)$ & $(2$ 列 $)$ & 0 & 0 & $(1$ 列 $)$ & $(2$ 列 $)$ \\
\hline 植生幅(m) & & & & & & \\
\hline
\end{tabular}
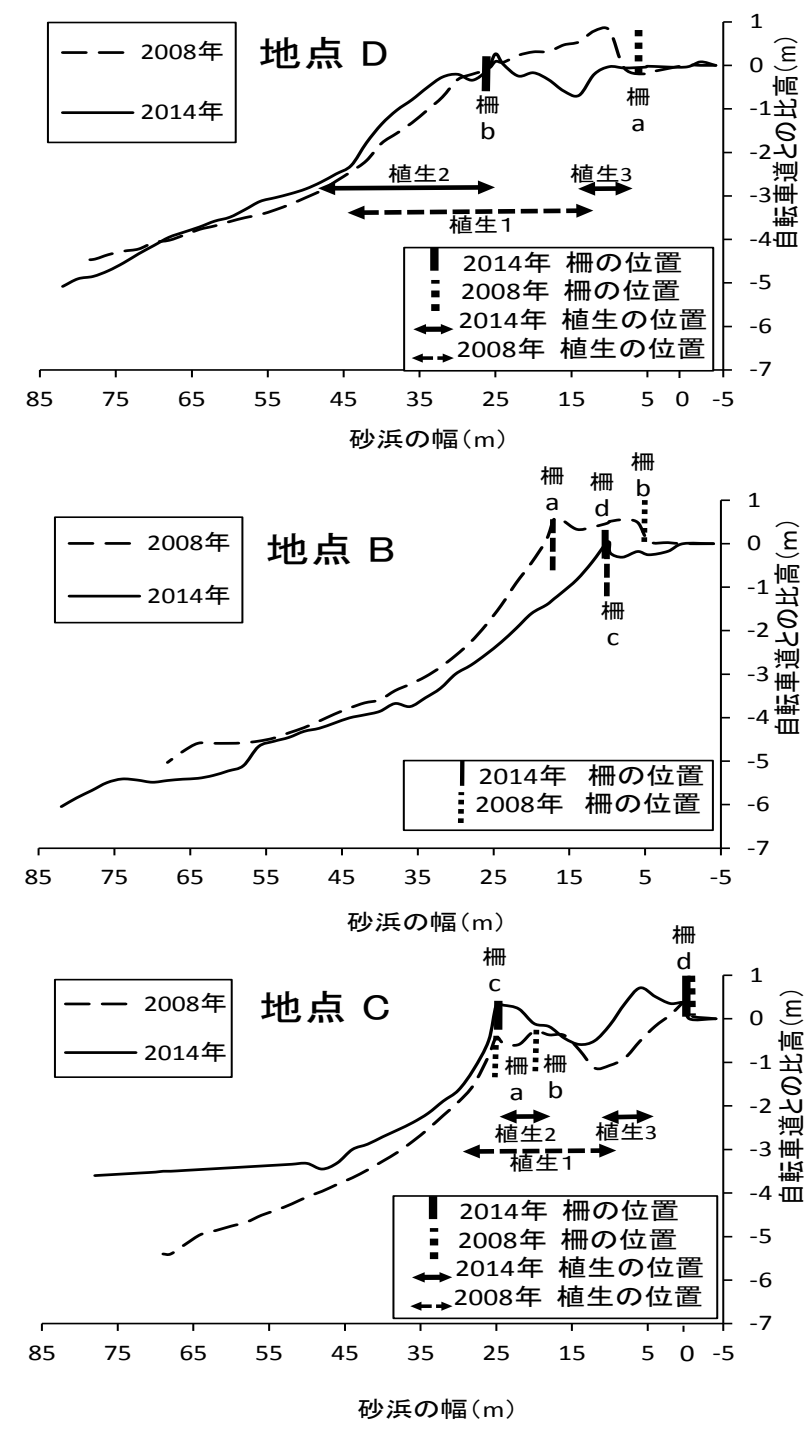

図-6 6 年後の微地形の変化

Fig. 6 Change of micro topography from 2008 to 2014

\section{2 風環境亡微地形の変化}

図-7 9 は, 2008 年と 2014 年に作成した地形断面上に, 算 出した風速比を重ねて作成した風速分布図である。眓には, 相対風速の加速域（相対風速比 $100 \%$ 以上範囲）と減風域 (相対風速比 50\%以下の範囲 12）16)）を示した。なお図中の $\mathrm{X}$ 軸は, 自転車道端から汀線へ向から水平距離 $(\mathrm{m}), \mathrm{Y}$ 軸は汀 線からの高さを示している。

地点D（図-7）：2008 年以後, 砂丘の位置が汀線側に $15 \mathrm{~m}$ 移動したことにより, 減風域の範囲が汀線側一約 $10 \mathrm{~m}$ 広が つた。また，2008 年の砂丘の丘頂は自転車道脇の柵 a より 少し離れて形成されているが，これは設置された柵 $\mathrm{a}$ の密閉 率が約 $80 \%$ と高く, 飛砂が反射したために形成されたものと 推定される。更に，2014 年には柵 b が設置されたことで背 後が侵食を受け 11$)$, 砂丘の風背側脚部に凹地状の地形が形 成された。また自転車道側肩部には小丘状の地形も出現した。

地点 B (図-8) : 2008 年以前に設置された 2 列の柵 $\mathrm{a} ・ \mathrm{~b} の$ 上部にまで砂が堆積しているが，これは柵の設置順位に関係 していると考えられる。すなわち柵 $\mathrm{a}$ がまず設置されて砂丘 ができ，そこからの飛砂の侵入を防止するために柵 $\mathrm{b}$ が設置 された。そして柵 $\mathrm{a}$ と $\mathrm{b}$ の間に飛砂が堆積した結果, 両柵の 間に多量の飛砂が堆積されていったと考えられる。
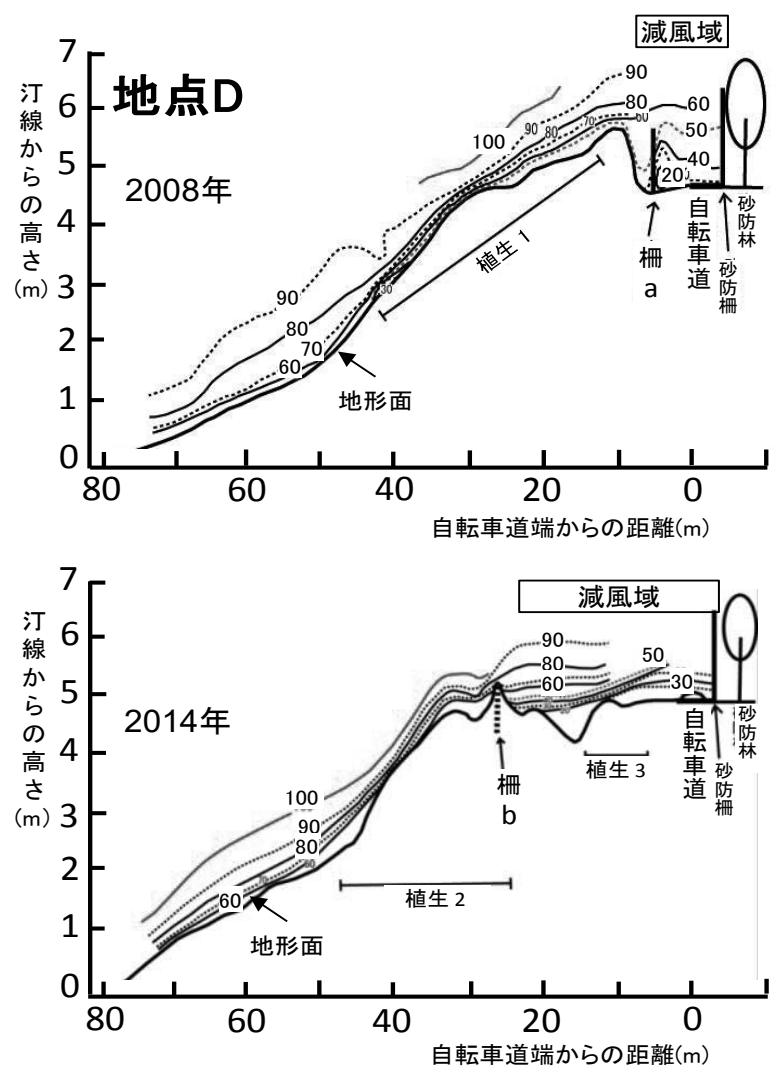

図-7 風環境変化と柵, 微地形及び植生との関係（地点 $\mathrm{D}$ )

Fig. 7 Relationship among wind conditions, sand fence, micro topography and vegetation of type D 

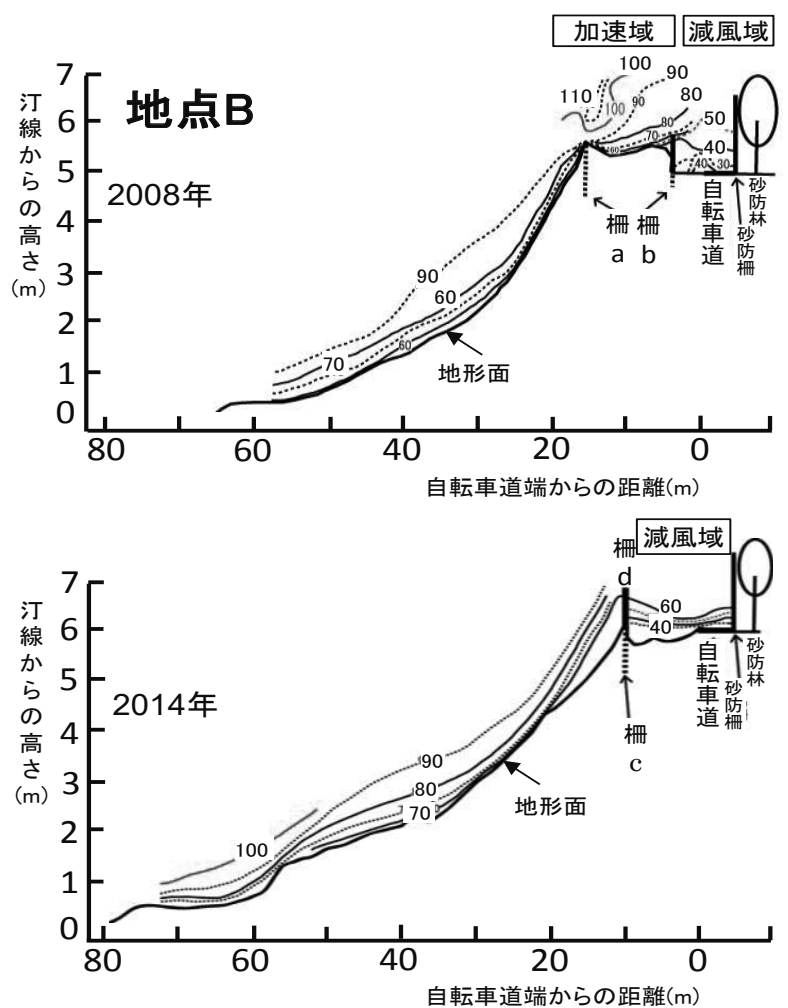

図-8 風環境変化と砂防柵, 微地形及び植生との関係（地点 B )

Fig. 8 Relationship among wind conditions, sand fence, micro topography and vegetation of type $B$

これは, 地点 $\mathrm{D}$ や地点 $\mathrm{C}$ の地形から推定できる。また，柵 $\mathrm{a}$ の南側の急傾斜により椢 a の上部に明瞭な加速域が確認で き, その背後に減風域が発生している。一般に傾斜が $0.3^{\circ}$ から $17^{\circ}$ の緩やかな地形では風は地表面に沿って流れる が，急な地形では頂上付近で最高風速を示す 14)。また障害物 がある場合には，風下に大きな後ろ風が生じることが知られ ている ${ }^{4)}$ 。そのために加速域で飛砂現象が活発になるととも に, 減風域には多くの飛砂が堆積する状況になったと推測さ

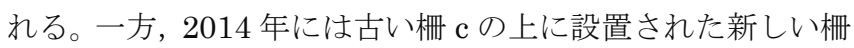
$\mathrm{d}$ の機能の発揮によって減風域の範囲は汀線側に広くなり, 加速域は消失した。また, 新しい㭗 $\mathrm{d}$ による砂丘は未発達で あり，地表面は自転車道よりも低く維持されていた。

地点 C（図-9）: 2008 年には 2 列の柵 $\mathrm{a} ・ \mathrm{~b}$ の間隔が短いた めに一つの砂丘として発達したと考えられる。そのために地 点 $\mathrm{D}$ の 2014 年と同じように柵の風背側に凹地が形成されて いる。柵 $\mathrm{a} \cdot \mathrm{b}$ 上には明瞭な加速域が確認され，活発な飛砂 現象が生じていたと考えられる。一方, 2014 年では, 古い㭗 $\mathrm{a} \cdot \mathrm{b}$ の上に設置された柵 $\mathrm{d}$ を中心と寸る砂丘と自転車道縁か ら約 $7 \mathrm{~m}$ ほど離れた位置に新たに砂丘が形成されている。こ 地点 D 22008 年（図-7 の上図）に見られるように, 柵に反 射した飛砂が堆積してできたものと考えられた。

\section{3 自転車道における堆砂量と 2014 年地形との関係}
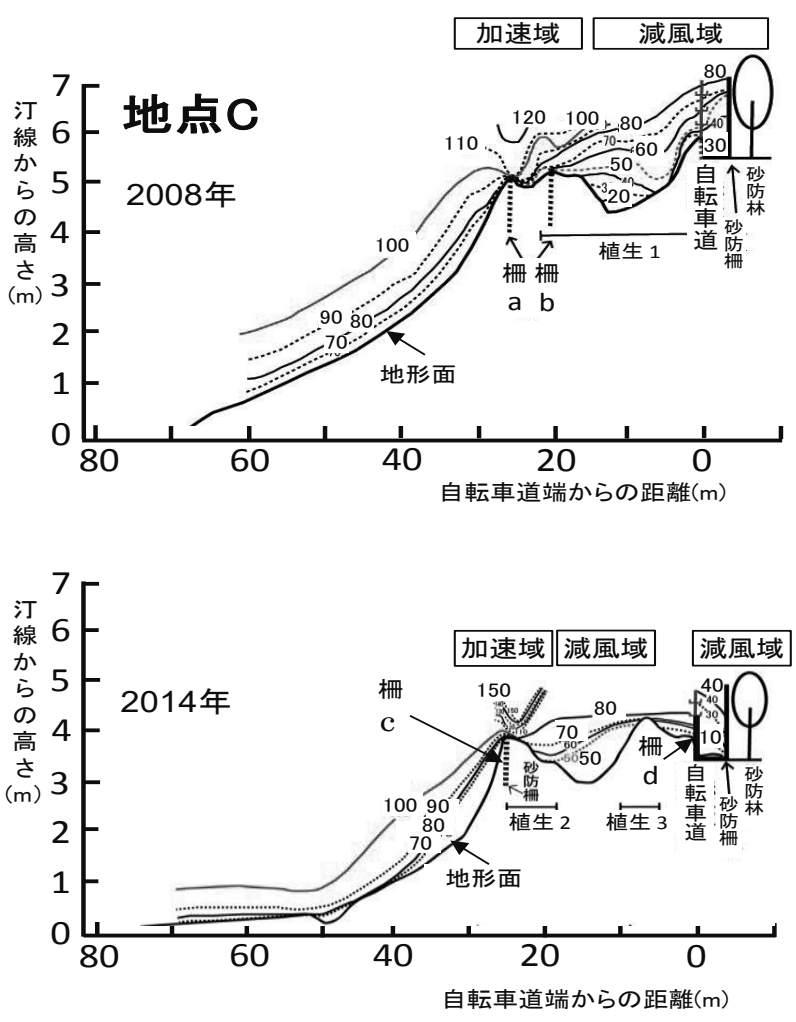

図-9 風環境変化と柵, 微地形及び植生との関係（地点 C)

Fig. 9 Relationship among wind conditions, sand fence, micro topography and vegetation of type C

表- 2 に, 2002 年・ 2004 年〜2006 年における各地点の年平 均除砂量 $\left(\mathrm{m}^{3}\right)$ 及び 2014 年に現地計測した各地点の自転車 道（1 m×4 m) に堆積した砂の容量を示す。表-2に示した ように, 2002 年及び 2004 年〜 2006 年の 4 年間の除砂量は 地点 $\mathrm{D}$ で最も多く, 次いで地点 $\mathrm{B}, \mathrm{C}$ の順であった。しかし, 椢の耐久年が約 2 年 11)であり, 本研究における地形測量年が 2008 年であるために, 過去の除砂量と地形との関係を明らか にすることができない。そこで前項までの検討結果に基づい て, 2014 年の堆砂量の解釈を次のように試みた。

地点 Dの 2014 年堆砂量は $44.93 \mathrm{~m}^{3}$ となり, 他の 2 地点よ りも多かった。地点 D では 2008 年以後にあらたに設置さ れた罒 $\mathrm{b}$ により丘頂の位置が汀線側に大きく移動し，その間 に凹地形が出現したことや, 植生も形成されたこともあり自 転車道一の飛砂は抑制されると予想された。しかし, 自転車

表-2 2002・2004 2006 年の除砂量及び 2014 年の堆砂量

Table 2 Amount of removed sands in 2002 • 2004 2006 and accumulated sands in 2014

\begin{tabular}{cccc}
\hline 地 点 & D & B & C \\
\hline 年平均除砂量 $\left(\mathrm{m}^{3}\right)$ & 111.5 & 74.03 & 16.17 \\
2014 年の堆砂量 $\left(\mathrm{m}^{3}\right)$ & 44.93 & 9.06 & 28.58 \\
\hline
\end{tabular}


道縁に柵が設置されていないこと, 自転車道と凹地の間に小 丘状の場所が出現し, これが飛砂の供給源になって堆砂量が 多くなっていると考えられた。

地点 Bの 2014 年堆砂量は $9.06 \mathrm{~m}^{3}$ であり, 他の 2 地点よ りも少なかった。2008 年時点では加速域の存在により飛砂現 象が活発で, 柵 $\mathrm{a} ・ \mathrm{~b}$ の間に溜まった大量の砂が自転車道側 へ押し出されていたと考えられるが, 2014 年には新たに設置 された柵 $\mathrm{d}$ が砂にとっての障害物として機能したこと, 砂丘 が未発達で地表面が自転車道よりも低位置にあること, 風の 加速域もないことなどから, 自転車道への飛砂の堆積も他の 地点に比べて少なくなったと考えられる。

地点 Cにおける 2014 年堆砂量は, $28.58 \mathrm{~m}^{3}$ であり, 地点 Dに次いで多かった。2008 年の地形は 2014 年の地点 Dの地 形と比べて凹地が深いことや， 凹地内には植生が成立してい たことから, 自転車道への飛砂の侵入は比較的少なかったと 考えられる。しかし 2014 年には自転車道から近い地点に小 丘状の地形が形成され, その脚部に溜まった砂が自転車道に 押出し始めることで, 自転車道への堆砂は今後増加すると考 えられた。

\section{4. まとめと今後の課題}

本研究の結果から，以下のことが考えられた。

1）柵の設置により柵上を丘頂とする砂丘が形成される。

2）形成される砂丘の南側（風衝側）が急傾斜で凹型地形の場 合は, 柵上に風の加速域が出現する。3) 形成された砂丘の北 側（風衝側）斜面は減風域となり堆砂が生じるが，柵と自転 車道との間が広い場合には凹地が形成される。4）自転車道と 柵の間に凹地が存在する場合, 飛砂は減風域である凹地内に 堆積するが, 凹地と自転車道の間に小砂丘が形成され，これ が自転車道の高さを越えるようになると, 自転車道への堆砂 （砂の押出し）が増加する。5）柵の密閉率が高い場合, 飛砂 は柵によって反射し, 風衝側に砂丘を形成する。

以上から, 柵の設置の有無や設置位置, 新設と砂中への埋 没が微地形の変化 (形成される砂丘の位置) に影響し, 微地 形の変化と柵の防風・防砂効果によって減風域の範囲や飛砂 が堆積する場所が変化することで, 自転車道への堆砂量（飛 砂害の程度）にも影響を与えることがわかった。

砂丘の丘頂部では風速の増大とともに飛砂量も多量となり 5), 柵で上方へ吹き上げられた飛砂はその風下へ吹き送られ， 後方の飛砂量を多く寸ることが知られている ${ }^{13)}$ 。今後, 飛砂 害を抑制するためには，柵の設置位置とそれによって生じる 減風域を予測し調整すること, また自転車道前面に自転車道 よりも低い凹地を形成させることや小丘の形成を防止するこ とが効果が高いと考えられる。また，柵の設置にあたっては 現存する植生の連続性を遮断しないことや 7), 砂表面におけ る飛砂の発生を抑制するための植生による被覆 ${ }^{11)}$, 柵によっ て飛砂を海側へ逃がす方法 ${ }^{15)}$ も有効であると考えられる。

鈴木(1981)によって, 「堆砂垣を連ねて出来た砂丘の頂に
起伏がある場合には, その起伏が次第に増幅され, 凹所の後 方の林帯に被害をもたらす例も多い。」11) と述べられている ように, 砂浜の安定や飛砂害の低減は, 砂浜後方の海岸防災 林を健全に維持していくために重要である。本研究では十分 な解析ができなかったが, 風環境や微地形の変化と植生との 関係や飛砂の粒径と植生との関係, 更には砂浜後方の海岸防 災林との関係についても, 今後検討する必要がある。

謝辞：本研究の遂行にあたり、神奈川県藤沢土木事務所よ り湘南海岸自転車道における飛砂量データをご提供いただき ました。心より御礼申し上げます。

\section{引用文献}

1）井上 晋(2012)今後における海岸防災林の再生について〜 「東日本大震災に係る海岸防災林の再生に関する検討会」 報告〜. グリーンエイジ, 39(5): 28-32.

2）神奈川県湘南なぎさ事務所(1997)白砂青松一湘南海岸の保 全と整備の歩み一.

3) 河合英二 (2010) 海岸環境と海岸林. 日本緑化工学会 誌,35(4): 513-517.

4) 真木太一(1987)風害と防風施設. 文永堂出版, 301pp.

5）松倉他(1979)風成デューンの風下斜面上における飛砂. 筑波 大学水利実験センター報告, 3: 47-53.

6) 村井宏他編(1992) 日本の海岸林一多面的な環境機能とその 活用一. ソフトサイエンス社, $512 \mathrm{pp}$.

7) 岡浩平・吉㠃真司・小堀洋美(2007)湘南海岸における地形 特性と砂防柵の有無が海浜植生の成帯構造の成立に及ぼす 影響. 環境情報科学論文集, 21: 87-92.

8) 岡浩平・吉㠃真司・小堀洋美(2008)静岡県遠州灘海岸にお ける海浜植生の成帯構造の成立要因. 日本緑化工学会誌, 34(1): 57-62.

9）坂本知己(2012）津波によって被災した海岸林の再生にむ けて. 水利科学, 56(3): 39-61.

10）佐々木寧他(2013)津波と海岸林一バイオシールドの減災効 果. 共立出版, 209pp.

11）鈴木 清(1981)湘南海岸における砂地緑化工に関する考察 緑化工技術, 8(2): 17-21.

12）鈴木 清(1984)湘南海岸砂防林の生長と林形に関する風洞 実験. 神奈川県林業試験場報告, 10: 23-35.

13）鈴木 清(1994)湘南海岸の飛砂の特性について. 神奈川県 林業試験場報告, 20: 45-61.

14）竹内清秀(1997)風の気象学,東京大学出版会.

15）宇多ら (2008)湘南海岸における飛砂量の検討. 海洋開発論 文集, 24: 1195-1200.

16）山野井克己ら (2001)海岸林の樹高成長に及ぼす間伐材防風 柵の効果. 日林誌, 83(2): 143-149.

17）吉㠃真司(2012)今日の海岸林の課題,水利科学. NO.326（第 56 巻第 3 号) 14-27.

18）財団法人電力中央研究所技術第二研究所(1971)飛砂と海岸 砂防に関する調查, 技術第二研究所報告 調查報告 71002 , $29 \mathrm{p}$.

(2017 年 6 月 19 日受理) 